\title{
The Ethics of Library Discard Practices
}

\author{
By: Rosann Bazirjian*
}

Bazirjian, Rosann. "Ethics of Library Discard Practices.” The Acquisitions Librarian 3: 135-146 (1990). [Also published in Legal and Ethical Issues in Acquisitions (edited by Katina Strauch) pp. 135-146, Haworth Press, New York (1990).]

\section{***Note: Figures may be missing for this format of the document}

\begin{abstract}
:
This paper explores the issue of ethics in relation to library discard practices, and attempts to address the weeding process from a philosophical point of view. An overview of some of the origins of ethical theories, including those of Kant, Epicurus and Epictetus, is given and related to college library weeding practices. Moral obligation is a key phrase when considering the concept of ethics. Honesty, objectivity, competency, and loyalty as they relate to the moral obligation most libraries have to keep their collections current, is examined. It is argued that these concepts do indeed substantiate the assumption that discarding is an ethical practice. Ethics has long been an area of concern to the American Library Association. An analysis of the professional status of librarians and the concept of ALA Codes of Ethics is addressed in this paper in order to place the issue in historical perspective. Finally, the issue of ethics versus law, and where discarding/weeding practices fit into that scheme, is discussed.
\end{abstract}

\section{Article:}

There are many reasons for weeding library collections. Some of them are justified while others are not. Since these reasons have been stated before, I will refrain from repeating all of the same old cliches. But, have we as librarians ever considered the ethical implications of the term "discards" or the significance of our actions when we discard titles? Is discarding an ethical practice? Why do some of us love throwing those books away, and others absolutely disdain it? Our strong feelings, one way or the other, are based on something we feel internally. These feelings stem from our conscience and are called ethics.

\section{DEFINITION OF ETHICS}

How do we define ethics? Ethics deals with what kinds of actions are right and wrong or good and bad, with the final judgement residing in an individual's conscience. What ought or ought not exist is measured by internal standards rather than by outside forces and is a result of individual belief. When the derivation of the word "ethics" is traced, one finds that it originally meant character, as opposed to intellect.' Attributing something to character and not intellect unconsciously gives it less credibility. Consequently, we are inferring that our actions stem from our emotions rather than from our minds.

Other aspects of the term ethics include professional conduct and moral obligation both to one's self and society. The forces which keep our actions within bounds are public opinion or personal conscience, both of which are in direct opposition to political law or state power. We measure

\footnotetext{
* Rosann Bazirjian is Head of Acquisitions/Coordinator of Collection Development, at the University of West Florida, John C. Pace Library, 11000 University Parkway, Pensacola, FL 32514.
} 
our sense of what is right and wrong by internal standards, not by a standard which has established legal criterion. As a result, we must be careful when considering the weeding process. Exploring the ethical issues involved in discarding practices used by libraries leads to an explanation of the way we feel about "de-selection" and from where these feelings originate.

\section{PHILOSOPHICAL THEORIES OF ETHICS AND THE COLLEGE LIBRARY}

Tracing the varying theories of ethics throughout the generations, a very interesting thread emerges. Historically, philosophical theories seem to substantiate the assumption that discarding is definitely an ethical practice. The following are highlights of some of the major philosophical theories related to ethics.

The utilitarian view of ethics states that the goodness of the consequence is what matters, and makes something ethically right. The philosophy of "goodness" is also an element of the philosophy of Immanuel Kant. Immanuel Kant (1724-1804) was a deeply critical philosopher whose profound thoughts led him to concentrate on science and its foundations. Kant believed that it is the goodness of one's motives which makes something right; that the mind orders all of our experiences; and that man's conscience reveals that moral precepts are necessary and valid. Our motives in discarding are to rid the library of superseded and damaged material and to make the library a dynamic place not one grown stiff in the joints. Many organizations do not meet their established goals "because of internal decay and rigidification." 2 As Frederick Wezeman so aptly states, "the cheapest, most effective, but often least used piece of library equipment is the wastebasket.'" Kant postulated that the rational nature of man is the basis for morality. Applying this theory to discarding library materials, a rational, organized approach to weeding can be viewed as truly ethical.

The idea of happiness and serenity of life was the primary concern of Epicurus (342-270 BC). He theorized that ethics meant achieving a thorough knowledge of the nature of things and that only this knowledge would rid one from superstitions and fear. If we understand why we discard and why the process is so beneficial, all the fears of making mistakes, or the superstitions about tossing out "sacred" items will disappear. Epicurus analyzed pleasure by arguing that it is the healthy condition of a being. Pleasure, he felt, should serve as the objective goal which determines our actions resulting in overall organization in our lives. The condition of "divine invulnerability"० can exist if we rid all contingency from our lives and through pure reasoning reach happiness and self-sufficiency.

A Roman stoic, Epictetus (336-264 BC), believed that it is the wise individual who limits his desires to what is within his reach and understands what is within his power, and that moral individuals live according to the dictates of reason. Applying this belief to our profession, college libraries need to understand exactly who they serve and the purpose of their collections and should not be striving to imitate those larger research libraries who perhaps might not need to weed their collections. If, as Epictetus believes, it is the attitude toward events rather than the events themselves which make something ethical, then our approach to discarding becomes all important.

\section{IS DISCARDING GOOD?}


What role then, if any, does ethics have in the discarding or weeding of library materials? We can start out very simply by asking the question "Is discarding good?" To discard. Webster's definition of discard is to "get rid of as useless or unpleasant.' Examine the words we use when discussing the "retirement" of titles from a library collection. Common expressions are purging, destroying, "out the back door," and trashing. We have inherited a negative connotation of what is a beneficial and necessary library function. The guilt we feel when "purging" our library collections merely gives this negative feeling credibility. Could we look upon discarding as an art, as a process which requires the same skill and competency as is needed in book selection or acquisition? If the answer is "yes," then is discarding "good"?

To many who study philosophy, the end result is what makes something good or bad. Would most people approve of standard discarding practices if they knew of the consequences? What are the theories underlying this practice? Discarding, or weeding, keeps book collections current, creates room on shelves for new titles, assures that patrons are receiving the most current information possible, removes damaged materials from our stacks, and eliminates multiple entries for a particular title from our computer files. Do these ends justify the means? Achieving the educational goals of a university or satisfying the needs of students in terms of collection development should be enough to answer this question with a "yes." Some philosophers, however, argue that a course of action is good only if it is approved by the majority of the people. When the consequences of a good weeding program are made public and the reasons why we discard materials support our own ethical opinions, then hopefully we have a satisfied clientele and our ethical judgments begin to direct others' opinions rather than merely describe them. A characterization of "goodness," then, leads to favorable interest, or so we hope.

\section{MORAL OBLIGATION}

The phrase moral obligation involves many components including: honesty, objectivity, competency, and loyalty. How one defines these will determine just how ethical library discarding practices appear. The conscience also plays a major role in determining our moral obligations. It is said that conscience is "the author of and the authority for our moral obligations."" Our conscience is what prompts us to perform our duties and in a sense becomes the supreme authority which makes us moral beings. Furthermore, the conscience acts as the regulating agent of our behavior and is the code which resolves conflicting personal and social interests. Everyone finds what is right inside of himself and this determines the moral code that he follows.

\section{Moral Obligation: Honesty}

The characteristic of honesty is closely related to conscience. Honesty is being truthful to oneself as well as to those you serve. Do we believe that the discarding of titles improves the quality of a library collection, or are we of the school of thought that believes that the "book not owned is a greater loss to some potential user than is one book too many?"" Library patrons are better served by the very best and current collection of books a library can offer. The term "library" is not synonymous with "museum." Other than certain primary sources and classics, the undergraduate library should not be housing "relics." Libraries only hurt the patron and possibly present him or her with misleading or even wrong information when outdated texts fill the shelves. A library patron is not helped by that outdated text he or she inadvertently picks up because he did not notice that the last line of the call number was 1972 and not 1989. Not only 
would the frustration factor for patrons be reduced, but library usage would in all likelihood increase due to the inspiration of accurate, timely information easily located on the library shelves. As librarians, we have an obligation to be aware of our clients' needs in relation to current curricula. It is important to take a careful look at the library collection to make sure it has indeed changed with "the times," since a library shelf full of outdated material gives the library user a bad impression of the institution.

In terms of a library collection, honesty involves the willingness to give items up. As Frederick Wezeman states, "how much support would the parks department receive if it permitted the golf courses to be overrun with weeds."' Dead titles are not only expensive to house, but also hinder a library's goals as well. In a time when so many libraries are running out of physical space, the need to weed our collections becomes ever more critical. One should not rely on alternatives such as physical library expansion or the presence of CD-ROM. Physical expansion requires funding which is not always available, and many libraries are not yet prepared to discontinue paper copies in favor of the as yet "unproven" CD- ROM technology. Although Interlibrary Loan, which makes one library's resources available to another library, is an alternative which might make the thought of discarding a bit easier, libraries must honestly make the necessary decisions to discard some materials.

\section{Moral Obligation: Objectivity}

Objectivity is another moral obligation. So much of ethics involves mental dispositions such as personal taste and subject matter biases. The professional who remains objective could be considered cold-hearted or uncaring. Can the librarian remain objective when selecting titles for discard? Does one discriminate when considering items on a title by title basis? It is important that librarians remain impartial and always base discarding decisions solely on criteria valid for their particular institution. As Seneca said, "Let us train our minds to desire what the situation demands."' The assessment of what is to be discarded should be based on user needs, not individual taste. Such is the idea of ethics which is based upon shared interests. Discard decisions should be based on what is best for our clientele, else, the action would indeed be unethical because it would take into consideration an individual's beliefs rather that the interests of all the patrons. The existentialist view of ethics is that nothing, not even God's will, can relieve an individual of having to make choices and decisions; no universal principles can sanctify what we decide. We are responsible for actions that are under our own control and need to make discard decisions based on objectivity and professional judgment. Objective knowledge frees one's mind from error and emotional conflict. This ethical theory expressed by Spinoza, says that one could never make a mistake if one remains objective.

Some would argue that it is difficult for librarians to remain objective when it comes to books. Books are often regarded with awe as sacred objects and we are taught as children to love books and treat them carefully. We give books lifelike characteristics by calling them our "friends," and it is difficult to discard old "friends." Many books have specific memory associations for some individuals, and might even remind us that time goes by so quickly. We are used to discarding Pepsi cans or Coca Cola bottles, but certainly not books. However, as Howard F. McGaw so aptly said, "If a book is not needed, it is only paper, ink, cardboard, and cloth, ready to be junked."'" Again, it becomes significant to remain above individual conscience and strictly adhere to required criteria. 


\section{Moral Obligation: Competency}

Moral obligation also involves competency. When librarians are hired, it is assumed that they will fulfill their job assignments, and be trusted to do what is in the library's best interests. Trust is earned by the competent librarian; by the individual who honestly explains the significance of his actions; who supports his decisions; and who remains true to his or her beliefs. "A professional's obligation to a client are those necessary to deserve the client's trust that these activities will be performed in a manner to promote the client's interests."" Patrons need to trust librarians to do what the patron wants, as well as to do what we are hired for. A conservative approach or that old-fashioned squirrel instinct are not in the best interests of the undergraduate library. One must remember that the potential for discarding grows stronger every year a book sits unused on a library shelf. "It is the sign of a healthy condition of the book collection and a wise administration of the book fund when the library's annual report reveals a fair correspondence between the number of new books regularly purchased and the number of books regularly discarded."'

\section{Moral Obligation: Loyalty}

A final component of moral obligation is loyalty. The concept of loyalty takes motives and intentions into consideration. As librarians, we shape and determine our book collections and service policies by molding the library into what we feel, in conjunction with our administration, is the most efficient way to operate. We make the library work and we make it either good or bad. Loyalty to the university's goals, to our administrators' beliefs, and to our patrons needs is part of what makes us professionals. The loyalty to our book collections is what should be leading us to discard. We want the best collection we can have, and that can only be accomplished through a steady weeding practice.

\section{AMERICAN LIBRARY ASSOCIATION AND ETHICS}

A review of the literature reveals that the topic of ethics has been a concern of the library profession for some time. Since 1929, the American Library Association has considered adopting official statements on ethics; however, even the final draft in 1981 remains of little significance to the profession. Unfortunately, many librarians are unaware that a "Code of Ethics" exists. Ethical codes are well established for many professions, most notably those in law and medicine. Perhaps the lack of a well-publicized ethics code for librarians is why we are sometimes referred to as "semi-professional." "In some contexts, the term professional librarian simply means adequately trained."' As William J. Goode continues to say, the librarian is viewed as a "gatekeeper" and "custodian of the stock.""

Without a resolute ethical code, the profession encounters difficulty in obtaining the necessary respect and trust from its clientele. How then can the profession exert an influence or impose authority on its clients? Only when the librarian works within the patrons' demands rather than imposing his or her own, can a bond of respect and trust be established. "The public believes libraries, but not librarians, are important. At present, the librarian has little power over his clients."" Does discarding become an even greater stumbling block in terms of patron emotions when it is the library that is important, more so than the librarian's actions?

The librarian becomes a professional once librarianship attains the stature of a profession. To do that one must understand that one needs to serve the interests of society even if his or her decisions are not popular, i.e., discarding books. Librarians who view their roles solely as 
disseminators of information rather than as responsible decision makers hurt the profession. Unfortunately, the librarian's sense of obligation to serve sometimes hinders doing what is best for the institution. Because we are not always viewed as a profession, our patrons believe that it is their right to complain about things such as overdue fines and even book discard practices. Librarians know that our policies and practices are determined by our values; however, because of our "semi-professional" status, we can state reasons but not prove them to be correct. "Thus, the librarian accepts the task of facilitating the implementation or achievement of standards of excellence whose definition and custodianship belong to others. In the university library, the others are the professors."'

This is exactly why we take extra, time-consuming steps when we want to discard books. Some of us provide faculty members with a list of every title about to be withdrawn for their review, others surreptitiously take their books to the dumpster ten or more blocks away just so no one "catches us," and of course, we must remember to remove those covers and all markings that indicate that we ever owned the book. Wouldn't it be so much simpler if respect for our profession was so strong that there would be no question that what we selected to discard was right?

Until our profession is allowed to influence its constituency it will not be granted any sort of stature. Until it is understood that librarians possess professional skills, that we create the order in the library which makes it a valuable place to study and learn, we will be considered nothing more than custodians guarding the book collection. The ability to function effectively, with objectivity and honesty, in harmony with ethical values, is essential to professional performance.

\section{ETHICS AND LAW}

In this day and time, a review of ethics relating to the discarding of library books must also include the relationship between ethics and law. Whereas ethics deals with perfecting an individual's character, law tends to concentrate on an individual's relation to other men. The authority of law lies within the "external individuals mind, which is ethics. There is a common meeting ground between law and ethics in that the rules of ethics that determine our inner thoughts will influence these "external manifestations" as well.

As mentioned earlier, ethics is determined by public opinion, whereas law is enforced by political codes. But, let's think about this connection. When we discard material from libraries, we need to be politically careful lest the faculty notice the dumpster nearby. When a group such as the faculty strongly oppose library discard practices, a force called public opinion emerges. If that opinion is very strong and long lasting, it will "eventually crystallize into law." It might only be the university's law, but nonetheless it is just as binding and possibly just as restrictive.

Librarians working at state universities are also confronted with legal issues when making discard decisions. Books are purchased with state funds, therefore making them state property paid for by taxpayers' money. Do we, as librarians, have a legal right to discard material purchased with state funds? Many state institutions are free to offer their discarded material to other non-profit institutions or to various international programs sponsored by the university. The ultimate disposition of withdrawn materials from state institutions that cannot be placed elsewhere is extremely complicated, and the true laws governing their disposition vary from state 
to state. Consequently, librarians need to be very competent, diligent, truthful and politically careful when participating in a weeding procedure.

CONCLUSION

The following is a quotation from Oliver A. Johnson's book entitled Ethics: Selections From Classical and Contemporary Writers. "Actions are right in proportion as they tend to promote happiness, wrong as they tend to produce the reverse of happiness."" In other words, what is right for one may be wrong for another, and it is not possible to please all of the people all of the time. In short, we all have our own beliefs by which we judge others' actions to be either good or bad, or right or wrong. We all follow our own moral theories and try to eliminate from our lives all conflict or question of those theories. If we can begin to understand the reasons behind our moral judgments, we will then be taking the first step toward seeking an ethical theory answering the question, is discarding library books ethical?

REFERENCES

1. Geo. W. Warvell, Essays in Legal Ethics, Littleton, CO: Fred B. Rothman \& Co., 1980. p. 3.

2. Laurence J. Peter, Peter's Quotations, Toronto: Bantam Books, 1977. p. 267.

3. Frederick Wezeman, "Psychological Barriers to Weeding," Bulletin of the American Library Association, 52 (8) (September 1952): 638.

4. Phillip Mitsis, Epicurus' Ethical Theory: The Pleasures of Invulnerability, Ithaca, NY: Cornell University Press, 1988. p. 1.

5. Webster's New Collegiate Dictionary, Springfield, MA: G \& C Merriam Company, 1974. p. 324.

6. Ethel M. Albert, Great Traditions in Ethics, Belmont, CA: Wadsworth Publishing Co., 1984. p. 169.

7. Arthur Curley and Dorothy Broderick, Building Library Collections, Metuchen, NJ: Scarecrow Press, 1985. p. 308.

8. Frederick Wezeman, op. cit., p. 639.

9. Laurence J. Peter, op. cit., p. 274.

10. Howard F. McGaw, "Policies and Practices in Discarding," Library Trends 4 (3) (January, 1956): 271.

11. Michael D. Bayles, Professional Ethics, Belmont, CA: Wadsworth Publishing Co., 1989. p. 74.

12. Howard F. McGaw, op. cit., p. 276.

13. William J. Goode, "The Librarian: From Occupation to Profession," Library Quarterly 31 (4) (October, 1961): 312.

14. Ibid., p. 313.

15. Ibid., p. 316.

16. Ibid., p. 318.

17. Geo. W. Warvelle, op. cit., p. 11.

18. Ibid., p. 15.

19. Oliver A. Johnson, Ethics: Selection from Classical and Contemporary Writers, New York: Holt, Rinehart \& Winston, 1965. p. 239.

\section{BIBLIOGRAPHY}

Albert, Ethel M. Great Traditions in Ethics. Belmont, CA: Wadsworth Publishing Co., 1984. Bayles, Michael D. Professional Ethics. Belmont, CA: Wadsworth Publishing Co., 1989. 
Curley, Arthur, and Broderick, Dorothy. Building Library Collections. Metuchen, NJ: The Scarecrow Press, Inc., 1985.

Evans, G. Edward. Developing Library and Information Center Collections. Littleton, CO: Libraries Unlimited, Inc., 1987.

Goode, William J. "The Librarian: From Occupation to Profession." Library Quarterly 31 (4) (October 1961): 306-320.

Hauptman, Robert. "Overdue." Wilson Library Bulletin 50 (8) (April 1976): 626-627.

Johnson, Oliver A. Ethics: Selections From Classical and Contemporary Writers. New York, NY: Holt, Rinehart and Winston, 1965.

Lindsey, Jonathan A., and Prentice, Ann E. Professional Ethics and Librarians. Phoenix, AZ: Oryx Press, 1985.

McGaw, Howard F. "Policies and Practices in Discarding." Library Trends 4 (3) (January, 1956): 269282.

Mitsis, Phillip. Epicurus' Ethical Theory: the Pleasures of Invulnerability. Ithaca, NY: Cornell University Press, 1988.

Peter, Laurence. Peter's Quotations. Toronto: Bantam Books, 1977.

Peterson, Kenneth G. "Ethics in Academic Librarianship: the Need for Values."

The Journal of Academic Librarianship 9 (3) (January 1983): 132-137. Reed-Scott, Jutta.

"Implementation and Evaluation of a Weeding Program." Collection Management 7 (2) (Summer 1985): 59-67.

Stueart, Robert D. "Weeding of Library Materials - Politics and Policies." Collection Management 7 (2) (Summer 1985): 47-58.

Tong, Rosemarie. Ethics in Policy Analysis. Englewood Cliffs, NJ: Prentice-Hall, Inc., 1986.

Warvelle, Geo. W. Essays in Legal Ethics. Littleton, CO: Fred B. Rothman \& Co., 1980.

Webster's New Collegiate Dictionary. Springfield, MA: G \& C Merriam Company, 1974.

Wezeman, Frederick. "Psychological Barriers to Weeding." Bulletin of the American Library Association 52 (8) (September 1952): 637-639. 